\title{
ZNF423 wt Allele
}

National Cancer Institute

\section{Source}

National Cancer Institute. ZNF423 wt Allele. NCI Thesaurus. Code C104960.

Human ZNF423 wild-type allele is located in the vicinity of $16 q 12$ and is approximately $370 \mathrm{~kb}$ in length. This allele, which encodes zinc finger protein 423 , plays a role in differentiation and maturation of olfactory receptor neurons. Mutations in this gene are associated with Joubert syndrome 19 and nephronophthisis 14 . 